\title{
AZ OUTSOURCING ÉS AZ INTEGRÁCIÓ KÖZÖTTI VÁLASZTÁS SZEMPONTJAI, AVAGY MINŐSÉG TESZI A DÖNTÉST
}

Jelen tanulmány azt a kérdéskört vizsgálja, hogy az outsourcing és az integráció nyújtotta lehetôségek közül adott esetben melyiket célszerú választani. A vizsgálódáshoz a lehetőségek széles körének feltárása, rendszerezése, valamint a fogalmak tisztázása biztosítja az elméleti alapot. Az általános érvényú megközelítések vizsgálatát követốen a szerzố a gyártás témakörére szúkíti a témát. A szakirodalom legújabb eredményei mellett esettanulmányok tanulságai is nagy szerepet kapnak az új döntési rendszer felállításában. A döntés elốkészítésében nagy horderejú, az outsourcing vagy integráció kimenetelére jelentôs hatást gyakorló szempontokat, igen-nem típusú kérdéseket fogalmaz meg. Az ezekre adott válaszok elôzetes elemzésként szolgálnak annak megállapítására, hogy van-e valamilyen választási lehetôséget kizáró ok.

Kulcsszavak: outsourcing, bi-sourcing, vertikális integráció, horizontális integráció, versenyprioritási tényezók, minốség

A termékek többségének előállítása meglehetôsen komplex feladatot jelent a vállalatok számára. Az eladásra „szánt” output jellemzően számos folyamat eredményeként jön létre, emellett a piaci körülmények is folyamatosan változó feladatokat fogalmaznak meg. A vállalatok így gyakran szembesülnek azzal a problémával, hogy nem képesek egymaguk eredményesen helytállni, ezért egy vagy több másik piaci szereplőhöz fordulnak. Az együttmúködés megvalósulhat egyszerúbb szerződéses formában vagy vállalategyesülésként. Mind az outsourcing, mind az integráció alkalmazása rendkívül elterjedt a gyakorlatban, érdemes megvizsgálni tehát, hogy valóban célravezetô-e ezen példák valamelyikét követni, illetve milyen szempontokat célszerú megfontolni a döntés meghozatalakor.

Krajewski és szerzőtársai (2013) az ellátásiláncmenedzsment egy jelentôs kérdésének tekintik az outsourcing kiterjedésének fokát, mely azt jelenti, hogy a vállalat az ellátási lánc milyen kiterjedését látja el a saját forrásaiból, illetve beszállítók kapacitásának felhasználásával. Outsourcing esetén bizonyos folyamatokat beszállítók hajtanak végre. Amennyiben a vállalat maga oldja meg a gyártást, úgy vertikális integrációról van szó. A szerzók „,make-or-buy decision” néven emlegetik a kettő közötti választást, hiszen arról kell döntenie a vállalatnak, hogy saját maga végzi el az adott folyamatot (make, vertikális integráció) vagy külsố cégtốl vásárolja azt meg (buy, outsourcing). Elemzésünkben a vertikális mellett a horizontális integráció lehetőségét is figyelembe vesszük, kibővítve ezzel a témakört a vállalategyesülés alternatívájával.

A kutatás során részletesen megvizsgáltuk az outsourcing, az integráció, valamint ezek egyes változatai közötti választási lehetőségeket. A dolgozat elsődleges feladatának tekinti a különböző változatok, megközelítések feltárását, valamint fogalmuk tisztázását. A kapcsolat szorossága, valamint a gyártási tevékenység irányultsága alapján felvázolt lehetőségek mátrixában rendszereztük a döntési lehetóségeket, melyek értékelési szempontjait a szakirodalom megállapításai mellett esettanulmányok segítségével állítottuk össze. Az értékelés javasolt módját a több szempontú döntéshozatalból ismert AHP struktúrájában vázoltuk fel. Vizsgálódásaink alapján az alkuerô, a bizonytalanság, az innováció és a négy versenyprioritási tényező (minőség, költségek, idő, flexibilitás) tekintetében történő értékelést ajánljuk. Az elemzés során minden egyes szempontot javaslunk külön értékelni a minőség nézőpontjából is. 
A tanulmányban, valamint a kidolgozott döntési módszerben felhívjuk a figyelmet néhány olyan kérdés jelentôségére, melyek körültekintô megválaszolása sorsdöntó hatású lehet mind az outsourcing-integráció dilemma eldöntése, mind a vállalat jövője szempontjából.

A következó fejezetben az outsourcing és az integráció fogalmával, valamint azok változatainak feltárásával foglalkozunk. A választási lehetôségeket egy mátrixban foglaljuk össze, melynek elemeit vállalati példákkal is magyarázunk. A 2. szakaszban olyan esettanulmányokat tárgyalunk, melyekre a szakirodalmi megközelítések alkalmazása helytelen döntéshez vezetett. A 3. rész az elsố kettô tanulságainak felhasználásával részletesen kifejti és rendszerezi a javasolt döntési szempontokat. A tanulmány a megfogalmazott gondolatok szintéziseként kialakított döntési struktúra összegzó bemutatásával zárul.

\section{Outsourcing vs. integráció: hasonlóságok és különbségek}

\section{Az outsourcing}

Az outsourcing kifejezésnek egyrészt nem létezik tökéletes magyar megfelelóje, másrészt nem egységes a definíciója a külföldi szakirodalomban sem. Hinek (2009) szerint az 1980-as években jelent meg először az angol nyelvú szakirodalomban, majd a kilencvenes években vált vállalati trenddé. A különböző definíciókat tanulmányozva a szerzố az outsourcing szúkebb és tágabb értelemben vett definícióját fogalmazza meg. Szúkebb értelemben azt érti outsourcing alatt, ha egy vállalat egy korábban saját maga által ellátott tevékenységet egy vagy több külső, jogilag és szervezetileg tốle különálló vállalatra bízza, miközben saját belső kapacitásait leépíti. Tágabb értelemben ugyanakkor beleérti minden, a végtermék előállításához szükséges alkatrész, részegység, illetve továbbértékesített késztermék beszerzését, valamint a bérmunkára vonatkozó bármely szerződés megkötését.

Az Outsourcing Institute (2012) felmérése szerint a vállalatok elsősorban költségeik csökkentése és kontrollálása céljából helyezik ki valamely tevékenységüket. A költségcsökkenésnek számos eredôje lehet, ilyen például az olcsóbb munkaeróból származó költségmegtakarítás. A dolgozók képzésének költségével sem kell számolni, amennyiben olyan jellegú tevékenység kiszervezéséról van szó, amelyre szakosodott cégek megfelelő humán erőforrására biztonsággal lehet támaszkodni. A kiszervezett tevékenységre specializált vállalat ráadásul rendelkezhet olyan technológiával, melynek megvásárlása és alkalmazása jelentős pénzforrásokat igényelne az anyacégtól.
A megkérdezett vállalatok második helyen rangsorolták azt a már részben érintett lehetôséget, hogy a vállalat azokra a területekre koncentráljon, melyek stratégiai jelentôségúek számára. A világszínvonalú képességekhez, valamint a tevékenység szempontjából fontos eróforrásokhoz való hozzájutás szintén az élmezónyben szerepelt. A válaszadók több, pénzügyi jellegú szempontot is megfogalmaztak, ezek közé tartozik a jelenben bizonytalan kimenetelú beruházási döntések késốbbi idôpontra való kitolásának lehetôsége, a jobb tốkeellátottság, valamint a kockázatok megosztása.

A fentiekben felsorolt potenciális előnyöknek természetesen megvan az ára. Ezt érthetjük egyrészt szó szerint, hiszen a partnercégek nem vállalnak ingyen kockázatot, a kiszervezésre esố profit jelentôs hányada az ô pénzügyi eredményükben jelenik meg. Téves lenne azonban azt állítanunk, hogy a kiszervezô annyi profittól esik el, amennyi többlet a másik szerződőnél keletkezett. Jól megalapozott outsourcingdöntés esetén ugyanis hatékonyságnövelés történik, csökkentve a termelés, szolgáltatás fajlagos költségeit.

Ahogy a fentiekben utaltunk rá, az outsourcing tárgya stratégiai jelentôségú kérdés. A kiszervezés vonatkozhat fő-, illetve támogató tevékenységre. A lehetséges tevékenységi köröket az Outsourcing Institute honlapjáról gyújtöttük össze. Az outsourcing legnépszerúbb területe az információs technológiával kapcsolatos szolgáltatások (IT) egyre szélesedô köre. Üzleti folyamatok kihelyezésére (Business Process Outsourcing, BPO) is számos lehetôség nyílik, a fó kategóriák a következók: adminisztráció, emberi erôforrás (HR), pénzügyi és számviteli szolgáltatások, értékesítés és marketing, ügyfélszolgálat, szállítás, elosztás és logisztika, valamint a jelen munkában nagyobb hangsúlyt élvezô gyártás.

A tanulmányban az outsourcingot a kiszervezés, a tevékenységkihelyezés és az alvállalkozók bevonása kifejezésekkel helyettesítjük, mivel az outsourcing azon megvalósulási formájára koncentrálunk, melyben az adott vállalat alkatrészt, félkész terméket vásárol egy másik vállalattól. Ebben az esetben szerződéses viszony áll fenn a két cég között. A megállapodás a kiszervezô cég belsô értékláncának egy jelentôs részéról szól, a folyamat feletti ellenőrzési jogot átruházza a vállalaton kívüli félre. Nem határozza meg tehát, hogyan kell előállítani a szerződés tárgyát, csak az eredmény, az output lényeges, nem a megvalósítás módja.

Amennyiben a vállalat készterméket szeretne üzleti partnerétól vásárolni - melyet egyébként maga is gyárt -, úgy bi-sourcingról beszélünk. Ezzel növelni tudja kapacitásait, ami több fogyasztói igény kielégítéséhez vezet. Megfelelő szintú kapacitás esetén nem áll fenn 
annak veszélye, hogy hátralék miatt keresletet veszítene a vállalat. Bi-sourcing esetén tehát inkább kapacitás-, míg outsourcing esetén jellemzóen hatékonyságnövelés a vállalat célja. Goldratt és Cox (1984) alapján megjegyezzük, hogy a hatékonyságért vívott elvakult küzdelem sokszor a céljaival éppen ellentétes irányba viszi a vállalatokat. Önmagában a hatékonyság nem elég, hiszen a bevétel az eladott termékekból keletkezik. Ha rendkívül hatékonyan megtermelt készletek állnak például a raktárban, az olyan mértékben növelheti a költségeket, hogy a hatékonyságban - és a magas kapacitáskihasználtságban - elért eredmények erodálódnak, sốt negatívba fordulhatnak át.

\section{Az integráció}

Barthélemy (2003) szerint az outsourcing az integráció alternatívája. Az outsourcingnál szorosabb kapcsolatot, dinamikus együttmúködést jelent ugyanis a fúzió vagy vállalategyesülés, mely történhet vertikális vagy horizontális formában. A vertikális integráció során szállító és vevő, forrás- (upstream) és végtermékoldali (downstream) vállalatok egyesülnek. Párban áll tehát az outsourcinggal, viszont ez a fajta kapcsolat sokkal szorosabb, hiszen a korábbi üzletfelek már egy vállalatot képeznek, az esetlegesen felmerülő problémákat együtt kell tehát megoldaniuk. A korábbi kiszervezó gyakorlatilag lemond azon lehetőségéról, hogy alvállalkozót váltson. A horizontális integráció azt jelenti, hogy kettó (vagy több), hasonló terméket vagy szolgáltatást előállító versenytárs hoz létre egy új vállalatot. Kevésbé kötött megvalósulási formája tehát a bi-sourcing. A vegyes fúzió (conglomerate merger) olyan vállalati egyesülést jelent, mely során fuzionáló vállalatok gazdasági tevékenysége egymástól teljesen független. Érthető módon ez az egyesülési forma a legkevésbé gyakori, és jelen tanulmány szempontjából jelentősége elhanyagolható.

A vertikális integráció irányulhat elôre- (forward) vagy hátrafelé (backward integration). Mivel esetünkben forrásoldali tevékenységeket vizsgálunk, ezért a hátrafelé irányuló integrációt tekintjük az outsourcing alternatívájának. $\mathrm{Az}$ integráció létrejöhet vállalategyesüléssel, mely során új, közös cég jön létre, viszonylag kiegyenlített eróviszonyokkal. A felvásárlás útján történő integráció a beszállító beolvasztását jelenti, növelve ezzel az anyacég méretét és ellenőrzési területeit. Ezt a stratégiát folytatja az Apple, hiszen a specializáció helyett inkább a folyamatok széles körét egy tetô alá hozza (Knowledge@Wharton honlapja). Akvizíció útján, de horizontális integráció keretében került a Google tulajdonába a Youtube.

\section{A két lehetöség összevetése}

A szerződéses viszony és az integráció között tehát a vállalatok közötti kapcsolat szorosságában található a legnagyobb különbség, így nem véletlen, hogy az outsourcing gyakran előzménye a vállalategyesülésnek. Outsourcingviszonyból indult ki például a Disney és a Pixar vertikális integrációja (Barthélemy, 2011), de fúziójuk elôtt ugyancsak egymás beszállítói voltak a Volkswagen és a Porsche (Fear - Knoop, 2006, 2007). A Scharffen Berger és a Hershey egyesülését azonban csak versenytársi viszony elôzte meg (Snow et al., 2006), mindkét cég a csokoládék prémiumszegmensében tevékenykedett, integrációjuk értelemszerúen horizontális volt.

A választási lehetőségeket rendszerező mátrix (l. 1. ábra) elemei közötti határvonal tehát nem éles. A kapcsolat szorosságának, valamint a tevékenység irányultságának változása lehetővé teszi az átjárást az egyes kategóriák között.

1. ábra

A vállalatok választási lehetôségeinek mátrixa vállalati példákkal

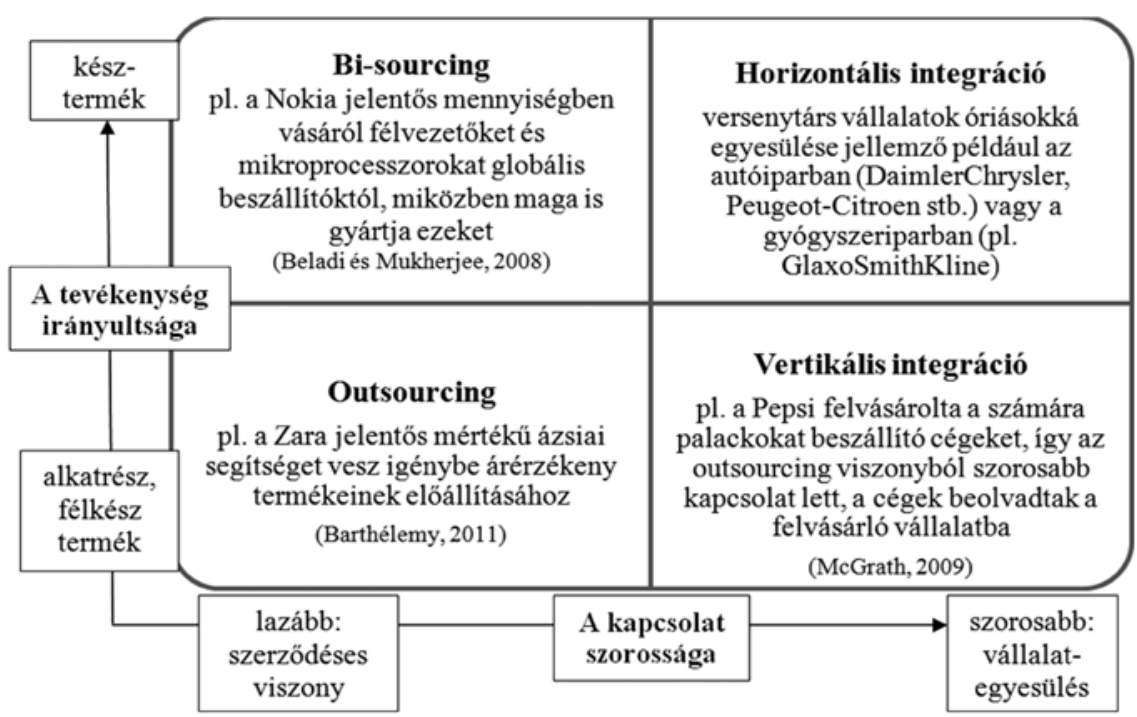

Bár számos további példát felsorolhattunk volna mind a kiszervezésre, mind az egyesülésre vonatkozóan, megemlítjük, hogy a bevett gyakorlat ellenére nem mindig célszerú ezek valamelyikének meglépése. Cohen (2007) óva inti a vállalatokat attól, hogy csupán azért alkalmazzanak outsourcingot, mert ez az aktuális trend. Szerinte a sikertörténetek következtében túlzott mérete- 
ket ölt a kiszervezés, mivel a vállalatok jelentôs része úgy gondolja, ez a megoldás minden problémájára. Ezzel tulajdonképpen egyetértve Collins (2001) arra hívja fel a vállalatok figyelmét, hogy a kiemelkedô cégek a felvásárlásokat lendületük felgyorsítására, nem pedig beindítására használják. Hayes és Abernathy (2007) hasonló megállapításokat tesznek a vállalategyesülésre vonatkozóan. Legyen szó akár tevékenységkihelyezésról, akár integrációról, a döntés elốtt számos tényezốt meg kell fontolni, a tanulmányban igyekszünk ezeket átlátható elemzési struktúrában tárgyalni.

\section{A szakirodalmi megközelítéseket szintetizáló döntési keret ütköztetése néhány vállalati esettel}

Az outsourcing és a vertikális integráció közötti döntés témájával foglalkozó szakirodalmi megközelítéseket Barthélemy (2011) három csoportra osztja:

- opportunista megközelítések,

- versenyelőnyre fókuszáló megközelítések,

- flexibilitás-központú megközelítések.

$\mathrm{Az}$ opportunista szemlélet szerint érdemes figyelembe venni azt a jelenséget, hogy az alvállalkozók, beszállítók gyakran nemcsak egyszerúen a saját malmukra hajtják a vizet, hanem opportunisták, bármikor megszeghetik a szavukat. Minél kevesebben vannak, annál nagyobb az alkuerejük a vállalattal szemben, és könnyen visszaélhetnek ezzel az erőfölénnyel. A szerzó azt javasolja, hogy a vállalatok akkor válaszszák a vertikális integrációt, ha nagy az esélye annak, hogy a beszállító opportunista magatartást fog tanúsítani. Amennyiben ez a veszély nem áll fenn, úgy az outsourcing a jobb megoldás.

A megközelítések második csoportja amellett érvel, hogy a vállalat akkor füzze szorosabbra kapcsolatát beszállítójával, ha annak erôforrásai és képességei magukban hordozzák a versenyelőny szerzésének lehetôségét az egyesült vállalat számára. Az erôforrásoknak és képességeknek ehhez négy kritériumnak kell megfelelniük: (1) teremtsenek értéket, legyenek (2) nehezen elérhetốk, (3) nehezen másolhatók, illetve (4) nehezen helyettesíthetốk. Amennyiben a beszállító nem rendelkezik ezekkel az előnyökkel, úgy célszerú a lazább, outsourcingviszonyt választani.

A flexibilitásra koncentráló érvek annál inkább az outsourcing mellett teszik le voksukat, minél nagyobb bizonytalanság övez egy meghatározott tevékenységet. A szerződéses viszony által nyújtott flexibilitás mellett azzal indokolják ezt a javaslatot, hogy a kiszervezóknek nem kell nagy mennyiségú pénzt fektetniük bizonytalan kimenetelú, kockázatos beruházásokba.

Barthélemy (2011) a három fenti megközelítés együttes figyelembevételét javasolja a döntés meg- hozatalakor. A Disney és a Pixar esetére bemutatja a döntési mechanizmust, igazolja annak helyességét. Az általunk választott példákra alkalmazva azonban téves következtetésekhez vezethet.

\section{A Mattel esete a kínai beszállítókkal}

A bemutatott szempontsort elsóként a legnagyobb amerikai játékgyártó, a Mattel példáján teszteljük. A szükséges információk forrása a Jiangyong et al. (2009), valamint a Wisner (2008) által készített esettanulmányok. A Mattel 2007-re gyártási tevékenységének mintegy 65 százalékát Kínába szervezte ki. A beszállítók magas száma, valamint a kiszervezett tevékenységek outputját övező bizonytalanság az outsourcing mellett szólnak. Potenciális versenyelőnyt az alacsony elóállítási költségek jelenthettek volna, ez az egy érv azonban önmagában nem elegendő a vertikális integráció meglépéséhez. Összességében tehát a szempontrendszert használva arra a megállapításra jutottunk, hogy a Mattel jól döntött, amikor kihelyezte gyártási tevékenységének jelentôs részét.

A valóságban azonban a cég minőségi problémák miatt jelentôs mennyiségú termék visszahívására kényszerült 2007-ben, nagy veszteséget szenvedve ezzel mind keresletben, mind hírnévben. Erre reagálva a Mattel bi-sourcing stratégiára váltott, azaz egyszerre kezdte el termelni ugyanazokat a termékeket és alkatrészeket otthon és külföldön. Ezzel egyrészt jobban kézben tudja tartani a minőség-ellenőrzést, másrészt alacsonyan tudja tartani költségeit. Jiangyong et al. (2009) azt a stratégiát javasolják, hogy az új termékek gyártását inkább belső kapacitásokból, míg a már régóta piacon levő játékok (pl. Barbie, Batman) előállítását kiszervezés útján oldja meg a Mattel. Ez a logika tehát épp ellentétes a flexibilitás-központú érveléssel, hiszen az új termékek gyártásának bizonytalansága jóval meghaladja a piacra már bevezetett, bevált játékokét.

Az esettanulmány tanulsága egyrészt, hogy létezhet - az általunk korábban be is mutatott - áthidaló megoldás az outsourcingintegráció-dilemma eldöntésére, ez pedig a bi-sourcing. Másrészt nem szabad, hogy elkerülje figyelmünket, hogy bizonyos szempontokból tapasztalható előnyök (pl. alacsony költségszint) más fontos tényezók (pl. minőség) rovására lehetnek. Harmadszor megemlítjük, hogy egy adott tevékenységet milyen méretekben kíván kiszervezni a vállalat. A 65 százalékos kihelyezés olyan aránynak túnik, melynek kontrollálása fokozott figyelmet igényel.

\section{A Toyota visszahívási problémái}

A Toyota termékeinek a Mattelénél is több, mintegy 70 százaléka készül beszállítóknál (Cole, 2011). Mind- 
ez önmagában nem feltétlenül probléma, különösen a Toyota esetében nem, hiszen ahogy azt számos szakirodalmi forrás (ld. pl. Spear - Bowen, 1999; Liker, 2004; Watanabe et al., 2007) bizonyítja, szorosan együttmúködik beszállítóival.

Az opportunista nézőpontot tekintve a beszállítók nagy száma, valamint az együttmúkködés szorossága az outsourcing mellett szól. Tovább erósíti az érvet a japán vállalati kultúra számos olyan kedvezô hatása, mint a megbízhatóság, az együttmúködés, a hosszú távú üzleti kapcsolatok (Sakai, 1990), vagy a kiváló minőség előállítására való törekvés (JUSE honlapja, honlapja).

Versenyelőnyhöz vezetố képességei azután lesznek igazán az egyes beszállítóknak, hogy a Toyota átadta nekik saját filozófiáját. Ennek megtanulása hosszú folyamat, de az együttmúköóst is hosszú távra tervezik.

Az autóiparban a keresleti ingadozások - különösen nehezebb időszakokban - fokozottan jellemzók. Egy esetleges gazdasági visszaesés az iparágakat tekintve először az autóiparban érezteti hatását. Outsourcing - és a Toyotánál első́ként alkalmazott just-in-time filozófia - alkalmazása esetén a keresleti bizonytalanságokból eredő kockázat jelentős része áthárítható a beszállítókra.

Ismét mindhárom megközelítés szerint jó döntésnek túnik az outsourcing választása. A cégnek azonban 2009 októberében mintegy 3,8 millió jármúvet kellett visszahívnia az USA-ban minôségi problémák miatt. Cole (2011) szerint a probléma két fô oka az volt, hogy a menedzsment túlságosan a gyors növekedésre koncentrált, a vállalat termékei pedig egyre bonyolultabbá váltak. 2003-tól kezdve a vállalat nem bírta belsố kapacitásaival követni az értékesítés növekedését. A vezetôség új beszállítók és munkaerô bevonását szorgalmazta, melyben a növekedés szempontja elónyt élvezett a minôséggel szemben. Mindez szemben áll a Toyota filozófiájával, általános versenystratégiájával. Garaventa és Tellefsen (2001) szerint ugyanakkor az outsourcingdöntésnek összhangban kell lennie a vállalat stratégiájával, az ellátási lánc teljesítményét ugyanis csak ebben az esetben tudja növelni.

A Mattel esetéhez hasonlóan az outsourcing negatív hatással volt a minőségre, de említést kell tennünk a Toyota példájának még egy további tanulságáról. A vállalat fejlesztési feladatainak ellátására több mint 30 százalékban külsős mérnököket alkalmazott (Cole, 2011). Ez azzal járt, hogy határozott idejú szerződésekkel foglalkoztatott olyan külföldieket, akik nyilván nem sajátíthatták el a cég kiválóságának alapját, a Toyota-filozófiát. A kiszervezés veszélyezteti a vállalat innovációs képességét, melynek tárgyalására az új szempontrendszer felírásakor visszatérünk.

\section{A Porsche-VW fúzió}

Harmadszor ismét az autóiparból választunk példát, melyben azonban fúzióról van szó, az eset tanulsága szempontjából pedig nincs jelentősége az iparágnak. A Porsche és a Volkswagen (VW) cégeket hosszú idốk óta szoros szálak kötötték össze. Bár mindkét vállalatot Ferdinand Porsche alapította, alapvetô különbség köztuik, hogy míg a Porsche drága luxusautókat, addig a VW „népautót”, elérhetốbb árkategóriájú „tömegterméket” gyárt. A Porsche ezért kevesebb terméket állít elô, kisebb vállalat, viszont magasabb haszonkulccsal dolgozik, mint a VW.

A két cég egymás beszállítói voltak, de közösen indultak el a városi terepjárók (SUV, sport utility vehicle) piacra dobásának útján. Ahogy arra Fear és Knoop (2006, 2007) esettanulmányai is felhívják a figyelmet, ezzel az együttmúködéssel nagy kockázatot vállalt a Porsche. Mind a partner személye, mind az új modell típusa nagy veszélyt jelentett a márkára nézve. Szüksége volt azonban a VW segítségére, hiszen a félmilliárd dollárt meghaladó beruházást nem tudta volna egyedül finanszírozni.

A szoros együttmúködés ellenére fúzióról sokáig nem esett szó. Ennek egyrészt anyagi okai voltak, másrészt viszont meglehetôsen eltért egymástól a két vállalat gazdasági versenyhez való hozzáállása. A Porsche elnök-vezérigazgatója, dr. Wendelin Wiedeking erőskezú vezetőnek számított, nem riadt vissza radikális változtatásoktól, leépítésektól, meglepó kiszervezési megoldásoktól. A Volkswagent ehhez képest jóval visszafogottabb lépések jellemzik, melynek több oka is van. Alsó-Szászország tartomány 20 százalékban tulajdonolja a vállalatot, melyhez az ún. VW-törvény értelmében vétójog is tartozik. Ez a törvény elöírja, hogy a cég bármely tulajdonosa a szavazatok maximum 20 százalékával rendelkezhet, bármekkora tulajdoni hányad is van a birtokában.

2005-ben mindezen tények ellenére Wiedeking úgy döntött, megvásárolja a Porschénél mintegy tizenötször nagyobb Volkswagent. Mindehhez a városi terepjárók sikeréből származó jelentős profit szolgáltatta a kiindulási alapot. 2009 januárjában már 50\% feletti részesedésnél járt, a cél azonban az irányításhoz szükséges 75 százalékos, teljes ellenőrzési jogot jelentő tulajdon megszerzése, valamint a VW-törvény hatályon kívül helyezése volt. Utóbbit az Európai Unió már elő is írta, megmaradt azonban a tartomány vétójoga. Mivel a Volkswagen jelentős tulajdoni hányaddal rendelkezett a svéd Scania teherautó-gyártó vállalatban, ezért a svéd törvények értelmében a Porsche vezetőségének ajánlatot kellett volna tennie a Scania részvényeinek megvásárlására is. A Porsche végül a VW megvásárlá- 
sához sem tudott idôben megfelelő pénzmennyiséghez jutni, így terve kudarcba fulladt.

2009 augusztusában fúzióról történt megállapodás, melynek létrejöttét az engedélyeztetés idôigénye mellett a felvásárlás kudarcából eredô peres ügyek is hátráltattak. A Volkswagen 2012 júliusában jelentette be, hogy mégis megvásárolja a Porschét.

$\mathrm{Az}$ eddigieket összegezve elmondhatjuk, hogy mindhárom esettanulmányra egyszerúen, egyértelmú válaszokkal alkalmazható a Barthélemy (2011) által javasolt szempontrendszer. A vállalatok az így kapott eredményeknek megfelelóen döntöttek, mégis olyan kudarc érte óket, melyet az outsourcingintegráció-döntés nagyban befolyásolt. Vizsgálódásainkat az 1. táblázat foglalja össze. Mindhárom esettanulmányra felírtuk, hogy a három nézőpont, ezeken keresztül a Barthélemyféle szempontrendszer milyen döntést javasol. Ez alapján mindhárom vállalat jól döntött, a gyakorlat azonban az ellenkezőjét igazolja. A levonható következtetések összefoglalását az utolsó sorban tüntettük fel. hez, hiszen a pénzügyi és jogi akadályok eleve nem tették lehetôvé az integráció megvalósulását. Éppen ezért egy olyan döntési mechanizmus kialakítását javasoljuk, amelyekben az ilyen jelentőségú körülmények nemcsak megjelennek, de még a részletesebb elemzés előtt kerülnek górcsố alá. A vélt választási lehetôséget kizáró ok feltárása meróben megváltoztatja ugyanis a döntési helyzetet.

\section{A döntés meghozatalához javasolt szempontok rendszere}

\section{Azelemzés elött tisztázandó, „vétójellegü"körülmények}

Mielőtt részletes, több szempontot figyelembe vevő elemzésbe kezdenénk, az esettanulmányok tanulságaiból okulva tisztáznunk kell néhány nagy horderejú kérdést:

1. Először is, végig kell gondolnunk, hogy mindenképp szükségünk van-e külső segítségre, az outsourcing vagy az integráció valamelyikére,

\section{A három nézópontú döntési keret alkalmazása a Mattel, a Toyota és} a Porsche példájára

\begin{tabular}{|c|c|c|c|}
\hline Nézôpont|Vállalat & Mattel & Toyota & Porsche \\
\hline Opportunizmus & outsourcing & outsourcing & integráció \\
\hline Versenyelóny & outsourcing & outsourcing & integráció \\
\hline Flexibilitás & inkább outsourcing & outsourcing & integráció \\
\hline Összességében & outsourcing & outsourcing & integráció \\
\hline Ellenérv a gyakorlatból & $\begin{array}{l}\text { visszahívások } \\
\text { minőségi problémák miatt }\end{array}$ & $\begin{array}{l}\text { visszahívások } \\
\text { minőségi problémák miatt }\end{array}$ & $\begin{array}{l}\text { a felvásárolni kívánt } \\
\text { Volkswagen részévé válik }\end{array}$ \\
\hline Következtetés & $\begin{array}{c}\text { költség-minőség } \\
\text { trade-off veszélye, } \\
\text { bi-sourcing lehetôsége }\end{array}$ & $\begin{array}{c}\text { növekedés-minőség } \\
\text { trade-off veszélye, } \\
\text { innovációs képesség fontossága }\end{array}$ & $\begin{array}{c}\text { jogi környezet, } \\
\text { pénzügyi helyzet jelentősége }\end{array}$ \\
\hline
\end{tabular}

A Mattel és a Toyota esetében mindhárom szakirodalmi megközelítés alapján az outsourcingmegoldás javasolt, azonban ennek alkalmazása mindkét esetben minôségi problémákhoz vezetett. Sem az opportunista, sem a versenyelôny-, sem a flexibilitás-központú nézópont nem tér ki a költségcsökkenés és a vállalati növekedés minőséget veszélyeztetô hatásaira. A trade-off persze nem áll fenn szükségszerúen, azonban nem hagyhatjuk figyelmen kívül annak lehetőségét. A minőségi romláshoz hasonló jelentőségú kockázat rejlik az innovációs képességek, lehetőségek csorbulásában, így a továbbiakban mindkét szempontot bevesszük az elemzési keretbe.

A Porsche esetében az integráció helyességére utaló jeleket a pénzügyi és jogi környezet kedvezőtlen volta vétózza meg. A minőség és az innováció szempontjainak vizsgálata sem vezetett volna el a helyes döntés- vagy ezzel a lehetőséggel akkor élünk csak, ha azt az elemzés eredményei indokolni fogják.

2. Ezek után még mindig kérdés, hogy szeretnénk-e a külsố segítséget egyáltalán belsôvé tenni, vagy csak az outsourcing jöhet szóba.

3. Amennyiben az integráció lehetőségét is fenntartjuk, mérlegelnünk kell, rendelkezésünkre állnak-e az ehhez szükséges mennyiségú pénzügyi források.

4. Ugyancsak inkább az integráció esetén fontos a jogi környezet pontos feltérképezése, valamint az annak megfelelő idôzítés.

A fentiek átgondolása az eset bonyolultságától függóen meglehetősen időigényes is lehet. Célszerú azonban előrehozni ezeket a kérdéseket, hiszen így nem juthatunk abba a helyzetbe, hogy a többi szempont 
alapján elkötelezzük magunkat egy olyan alternatíva mellett, mely például olyan jogi akadályokba ütközik, hogy alig van esély a megvalósítására. Amennyiben a négy kérdés tisztázása után is az outsourcing és az integráció - illetve annak két-két fajtája - közül kell választanunk, úgy a lenti szempontsor figyelembevételét javasoljuk.

\section{A döntést befolyásoló tényezók}

Az outsourcing és az integráció közötti választást négy fő szempont szerint vizsgáljuk, ezek az alkuerő mértéke, a bizonytalanság mértéke, az innovációs lehetôségek, valamint a termelési funkcióra eső négy versenyprioritás. Minden ismérvet külön vizsgálunk a minóség szempontjából. Egyetértünk ugyanis Deming azon állásfoglalásával, mely szerint a jó versenypozíció kulcsa a minóségmenedzsment célként való meghatározása (ld. Mann, 1987).

A Deming-filozófia szerint nem kell trade-offnak lennie a minőség és a termelékenység között. A minőség termékbe való beépítése mérsékeltebb költségeket, idômegtakarítást, termelékenységjavulást, összességében jobb versenypozíciót eredményez. Amennyiben ugyanis egy vállalat alacsonyan tudja tartani a gyengébb minôségú, tulajdonképpen selejtnek tekinthető termékek arányát, úgy csökkennek javítási és raktározási költségei, javul az anyagok, az eszközök és a munkaerő kihasználtsága, könnyebben be tudja tartani a határidóket, azaz összességében több ideje és erôforrása marad versenypozíciójának további erôsítésére.

\section{Az alkueró mértéke}

Az opportunista megközelítés (Barthélemy, 2011) alapján minél kevesebb beszállítója van egy cégnek, annál nagyobb azok alkuereje a vállalattal szemben. A kockázat diverzifikálása érdekében érdemesnek tûnik tehát minél több alvállalkozóval, beszállítóval szerződést kötni. A Deming-féle menedzsment (Mann, 1987) szerint azonban éppen ellenkezóleg, egyetlen beszállítót érdemes alkalmazni, aki kiváló minőséget tud garantálni és hosszú távú partner. Erre a következtetésre japán vállalatok megfigyelése során jutott, ahol a hosszú távú kapcsolat, szerződés nélkül is csaknem garantált, ahogy a minőségre fordított fokozott figyelem is. További érvünk az egyetlen szerződés mellett, hogy a konzisztens minóséget könnyebb úgy elérni, hogy nem több üzletféltól érkeznek a félkész termékek.

Bi-sourcing esetén az alkuerôt értelmezhetjük a piaci részesedés mértékeként. Ebben az esetben még inkább veszélyes lehet az opportunista hozzáállás, hiszen a szerződés már késztermékekrôl szól. Itt is meg kell győződni arról, hogy a másik fél képes és valóban hajlandó-e azt a minôséget biztosítani, mellyel a kiszervezô vállalatot a fogyasztók számon tartják a piacon.

Összességében tehát az integráció mellett szól, ha a másik fél alkuereje nagy, és egyébként olyan minőséget tud elérni, amely beleillik a kiszervező elképzeléseibe. Amennyiben az erőfölénnyel való visszaélés lehetősége meglehetôsen korlátozott, úgy a tevékenység kihelyezése célszerú, persze csak a minôségi feltételek teljesülése esetén. Előfordulhat, hogy a kiszervező nem talál olyan céget, amely megfelel a minôségi követelményeknek. Ekkor olyan vállalattal érdemes integrációra lépni, amely az egyesülés részeként már képes lesz elsajátítani az immáron közös minôségi tudást.

\section{A bizonytalanság mértéke}

Egy vállalat egészét nézve a legfontosabb bizonytalansági tényezô a rövid és hosszú távú kereslet. Nem mindegy, hogy egy rövid távú kilengésre vagy egy hosszú távú, volumenbeli változásra kell reagálnia a piaci szereplőnek. További bizonytalanság övezheti a szükséges inputok meglétét, valamint a minóségi outputot eredményezô transzformáció is számos kérdőjelet foglalhat magában.

Amennyiben a bizonytalanság átmeneti és/vagy nagymértékú, úgy outsourcing vagy bi-sourcing segítségével áthárítható a kockázat egy másik félre. Ezzel egyrészt időt nyerhet a kiszervezô, másrészt nincs szükség felesleges beruházásokra. Természetesen ennek meg kell fizetni az árát, melyet az előzőekben tárgyalt alkuerő is befolyásol.

A kiszervezéssel nyert idő segít abban, hogy a bizonytalanság változásától függően tudjon dönteni a késôbbiekben a vállalat. Amennyiben a kockázat csökken, úgy a szerződéses viszony fúzióvá alakítása célszerú.

A bizonytalansági szempontokhoz sorolhatjuk a korábban már tárgyalt jogi környezet kérdőjeleit, melyek érvként hozhatók fel egyik vagy másik megoldás javára.

\section{Az innováció}

Jellemzően nagyfokú bizonytalanság veszi körül a kutatási-fejlesztési tevékenységet, hiszen annak kezdetekor ritkán lehet garantálni, hogy eredményül olyan hasznos innovációval gazdagodik-e a megbízó, amely hosszú távon megtérül, sốt növeli a cég versenyképességét. Chou és Chou (2011) szerint, mivel a versenyképes szervezeteknek folyamatosan új termékeket és szolgáltatásokat kell kínálniuk fogyasztóik számára a piacon, ezért szükségük van innovációra. A $\mathrm{K}+\mathrm{F}-\mathrm{fel}$ járó magas költségek indokolhatják az outsourcing választását, a döntés előtt azonban megfontolandóak kockázati, termelékenységi és minôségi szempontok. 
A Mattel által alkalmazott bi-sourcing megoldás beleillik a Pisano és Shih (2012) által kidolgozott döntéstámogató mátrix rendszerébe. A szerzőpáros abból indul ki, hogy a termékfejlesztés sikeréhez nagyban hozzájárul, ha a vállalat saját maga gyártja termékeit. Magára a gyártásra nem szabad csak költség szempontjából tekinteni, hiszen gyakran benne rejlik az innováció lehetősége. Nehéz azonban eldönteni, mely esetben vezet a gyártás megtartása innovációhoz, illetve mikor szervezhetô ki biztonsággal. Meg kell vizsgálni, milyen esetekben tud egymástól függetlenül sikeresen múködni a kutatásfejlesztés és a gyártás, azaz milyen a modularitás mértéke. Ha alacsony, azaz nem kezelhetố külön a K+F és a gyártás, akkor az innovatív tudás nehezen adható át írott formában, vagyis fizikai közelségre van szükség. Nem célszerú tehát kiszervezni, fontolóra vehetô azonban az integráció lehetősége. Valamilyen szintú innovációs képességre minden vállalatnak szüksége van, az innovatív iparágakban tevékenykedóknek pedig versenyképességi szempontokból különösen fontos ez a nézópont.

Mivel a termék és a folyamat fejlesztése sokszor párhuzamosan történik, ezért a folyamat kiforrottságának is jelentôsége lehet, ez adja a mátrix másik tengelyét. Pisano és Shih (2012) szerint ahogy egyre érettebbé válik a folyamat, a fejlesztési lehetőségek jellemzően egyre kisebb mértékúek, csökkentve ezzel a kiszervezés kockázatát. Tiszta folyamatinnováció esetén a folyamat érettsége alacsony, de nem létfontosságú a fejlesztés közelében gyártani. Tiszta termékinnováció esetén már a termelési folyamat is érett szakaszban van, így kevesebb kockázattal jár a kiszervezés. A modularitás-érettség mátrixot a 2. ábra mutatja be.

\section{A modularitás-érettség mátrix}

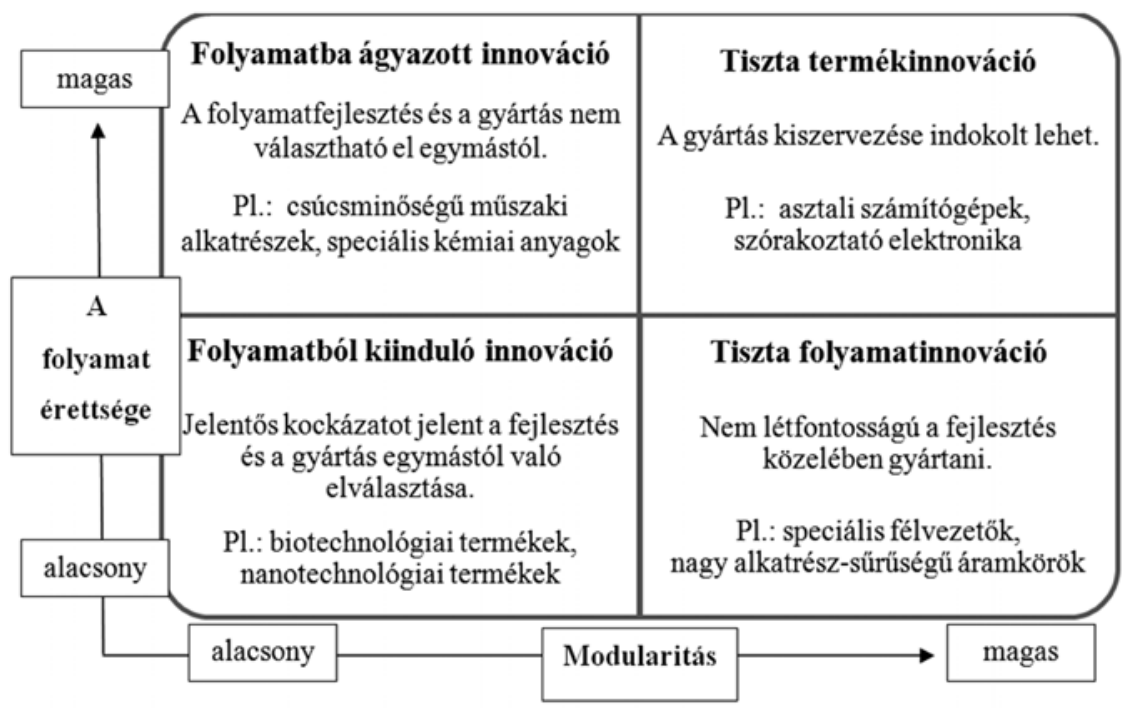

Forrás: Pisano és Shih (2012) alapján saját szerkesztés

\section{A négy versenyprioritási tényezó}

A stratégia alkotásának célja a kulcsképességek és -kompetenciák olyan felhasználása, mely gazdasági erófölény létrehozását eredményezi (Vörös, 2010). A kiszervezési döntés meghozatalakor ezért a vállalatnak pontosan kell definiálnia kulcsképességeit és -kompetenciáit, melyek figyelembevételével határozza meg, mely tevékenységeket, folyamatokat tart meg saját falain belül, illetve bíz másokra. Kroes és Ghosh (2010) felhívja a figyelmet arra, hogy az outsourcinggal kapcsolatos döntés minden egyes versenyprioritási tényezôre más intenzitással hat, ezért a stratégiában egyértelmúen meg kell határozni, melyekre fókuszál az adott vállalat.

A négy versenyprioritási tényezô közé a szakirodalom alapján (ld. pl. Krajewski et al., 2013 vagy Vörös, 2010) a költségeket, az időt, a minőséget, illetve a (volumen- és termék-) flexibilitást soroljuk. Mivel ezek közül egy tényezó javítása gyakran egy vagy több másik rovására megy, ezért vállalatok gyakran túzik ki azt a célt, hogy úgy váljanak kiválóvá az egyik versenyprioritásban, hogy a többiben se maradjanak le túlságosan versenytársaiktól. Az így kialakuló versenyelónyt értelemszerúen nem elég megszerezni, hanem a profitabilitás érdekében hosszú távon fenn is kell tartani, elkerülhetetlen tehát a folyamatosság. Nem véletlenül tartozik a kiváló minốséggel büszkélkedó Toyota Termelési Rendszer kulcselemei közé a hosszú távú szemlélet és a folyamatos fejlesztés (Watanabe et al, 2007).

A japán gyártók kultúrájára jellemző az együttmúködés, versenytársaikkal együtt alakítanak „minőségi köröket" (quality circle), melynek célja a minőséggel kapcsolatos tapasztalatok megosztása, ezen keresztül

2. ábra a minőség fejlesztése (JUSE honszállítóikkal is szoros kapcsolatban állnak, hogy a lehetô legjobb minôségú terméket tudják nyújtani fogyasztóiknak. A just-in-time akkor megvalósítható, ha a gyártás kontroll alatt van, a beszállítók pedig nagyon jó minőséget adnak kis szórással (Mann, 1987). Ennek mintájára a Ford is minden beszállítójától elvárja, hogy úgy gondolkodjon, ahogy ó, vagyis kövesse a Deming által a minőség biztosítása érdekében megfogalmazott 14 pontot.

A kiváló minőség elérése érdekében hasonló gondossággal válogatta meg beszállítóit a Scharffen Berger (Snow et al., 2006), mely jelenség egyébként az Outsourcing Institute 
szerint általánosnak mondható (Outsourcing Institute honlapja, honlap). Felmérésük szerint ugyanis a beszállító kiválasztásakor az elsố helyen szerepel a potenciális partner minôséghez való hozzáállása. Minőségi szempontnak tekinthetjük emellett a harmadikként rangsorolt hírnév kategóriáját is. Annak ellenére tehát, hogy az outsourcingcélok között elsố helyen szerepel a költségek csökkentése, a vállalatok igyekeznek kiszúrni a költség-minőség trade-off, valamint a márka erodálódásának veszélyét.

A beszállítók kiválasztásában második helyen az ár áll, melyet a költségekkel helyettesítünk. Egyetértünk ugyanis a Toyota azon véleményével, hogy olyan beszállítókkal érdemes üzletet kötni, amelyek költséghatékonyságuk következtében kínálnak alacsony árat (Toyota Supplier honlap), nem pedig átmeneti jellegú árcsökkentés révén.

A költségek alacsonyan tartásával kapcsolatban megállapíthatjuk, hogy ha az outsourcing segítségével nô a hatékonyság, az - a fentiekben már tárgyalt keretek között - csökkenti a költségeket. A bi-sourcing a kapacitást tudja növelni, melynek következtében nem kell attól tartani, hogy az alacsony kínálat miatt vevóket veszítene a vállalat. Megjegyezzük ugyanakkor, hogy az integrációhoz képest kisebb árréssel lehet így számolni.

Az idónél a gyors reagálás kulcsfontosságú lehet, a fogyasztó - különösen szolgáltatások esetén - a minőséget is jobbnak érzékeli, ha nem kell annyit várakoznia. Mivel szerződéses kapcsolat létesítése egyszerúbb, ezért gyorsabb az integrációnál (ld. Volkswagen-Porsche fúzió elhúzódása), rövid távon tehát ez a kifizetôdôbb.

A terméknél elért flexibilitást inkább outsourcing, a volumenflexibilitást a bisourcing segítheti elő. Fontos azonban, hogy a flexibilitás ne veszélyeztesse a minóséget, hiszen egy esetleges hiba után a hírnév romlását nehéz javítani.

\section{Összegzés és döntési javaslatok}

A tanulmányban egy olyan kiterjedt, mégis jól kezelhetô elemzési keretet állítottunk fel, mely segítséget nyújt azon kérdés eldöntésére, hogy adott esetben egy adott vállalatnak érdemes-e az outsourcing vagy az integráció mellett döntenie. Minden szituáció egyedi, az adott vállalatnak kell eldöntenie, milyen szempontokat tart meg, illetve vet el a felsoroltak közül. Természetesen az egyes szempontok nem egyformán fontosak, ezek súlyozása a helyzet mély ismeretét igényli. Tisztában kell lenni ezenfelül az egyes szempontok közötti összefüggésekkel, ahogy ezeket a fentiekben némileg feltártuk. Többször utaltunk emellett a minden szempont mögött meghúzódó, minőséggel kapcsolatos megfontolások fontosságára.

Mint minden értékelés, ez is jelentôs mértékú szubjektumot tartalmazhat, véleménykülönbségek nyilván elófordulhatnak. Árnyaltabb megoldást kapunk tehát eredményül, ha nemcsak több szempontú a döntéshozatal, hanem több döntéshozó is részt vesz benne. Az így felmerülô módszertani problémára megoldást adhat a Saaty (1980) által kidolgozott analitikus hierarchikus eljárás (analytic hierarchy process, AHP) módszere.

Az outsourcing vs. integráció kérdésére felírt AHP (3. ábra) nem tartalmazza azt az elózetes megfontolásra javasolt négy kérdést, melyekre adott válaszok elutasító vagy megengedő jelleggel viszonyulnak a probléma további vizsgálatához. AHP felírásának akkor van értelme, ha a négy kérdésre adott válasz egyike sem utasítja el az outsourcing vagy integráció melletti döntést, vagyis (1) a vállalatnak szüksége van külsố se-

3. ábra

A lehetséges alvállalkozó vagy fuzionáló vállalat értékelése AHP segítségével

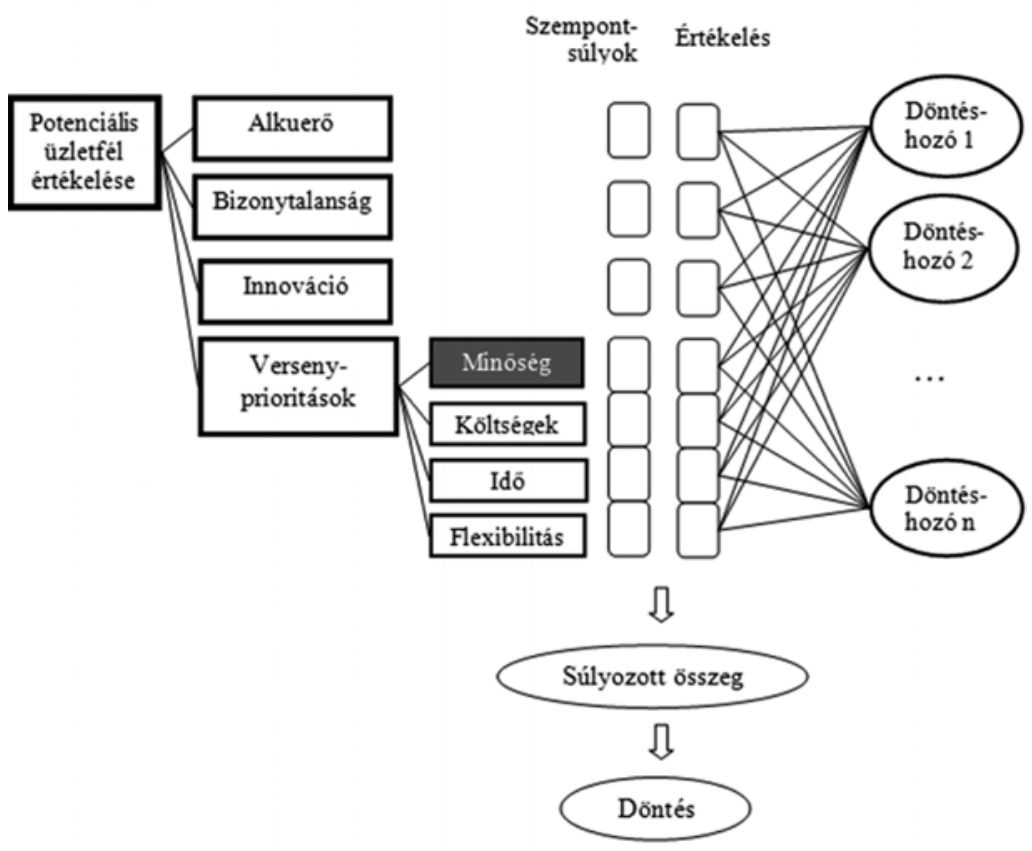

gítségre, melynek (2) belsővé tételét elképzelhetônek tartja, és (3) a pénzügyi, valamint (4) a jogi helyzet megfelelô. Ha ez a helyzet áll elő, akkor az AHP-t kitöltố kijelölt döntéshozók elsố feladata a szempontok súlyokkal való ellátása. Ezt a konzisztens értékelés érdekében célszerú a Saaty (1980) által javasolt páros összehasonlítás mátrixok segítségével megtenni. A po- 
tenciális üzletfelet ezután minden döntéshozó minden szempont szerint értékel szerződéses partnerként, illetve integrációra lépő vállalatként egyaránt. Amelyik tekintetben magasabb pontszámot ér el a vállalat, azt az üzleti kapcsolatot érdemes létesíteni. Természetesen alacsony eredmény esetén másik üzletfelet kell keresni.

Amennyiben a vállalat a másik féllel biztos az együttmúködés valamilyen formájának sikerességében, úgy egyszerúsítheti a döntési folyamatot aszerint, hogy minden szemponton belül csak úgy értékelnek a döntéshozók, hogy abban a tekintetben az outsourcing (bi-sourcing) vagy a horizontális (vertikális) integráció mellett döntenének. Így tulajdonképpen hétszer kell az integráció mellett vagy ellen voksolniuk, melynek súlyozott összege adja az eredményt.

\section{Felhasznált irodalom}

Barthélemy, J. (2003): The seven deadly sins of outsourcing. Academy of Management Executive, vol. 17, no. 2: p. 87-100.

Barthélemy, J. (2011): The Disney-Pixar relationship dynamics: Lessons for outsourcing vs. vertical integration. Organizational Dynamics, vol. 40: p. 43-48.

Beladi, H. - Mukherjee, A. (2008): Strategic bi-sourcing. University of Nottingham, Discussion Paper No. 08/06, elérhető: http://www.nottingham.ac.uk/economics/ documents/discussion-papers/08-06.pdf

Chou, D.C. - Chou, A.Y. (2011): Innovation outsourcing: Risks and quality issues. Computer Standards \& Interfaces, 33: p. 350-356.

Cohen, L. (2007): Stop compulsive outsourcing now. The Euromoney Outsourcing Handbook: p. 5-7.

Cole, Robert E. (2011): What Really Happened to Toyota? Sloan Management Review, Summer: p. 29-35.

Collins, J. (2001): Good to great. Why some companies make the leap... and others don't. Harper Business, New York

Fear, J. - Knoop, C. - I. (2007): Dr. Ing. h.c. F. Porsche AG (A): True to Brand? Harvard Business School, 9-706-018

Fear, J. - Knoop, C. - I. (2006): Dr. Ing. h.c. F. Porsche AG (B): Made in Germany. Harvard Business School, 9-706-019

Garaventa, E. - Tellefsen, T. (2001): Outsourcing: the hidden costs. Review of Business 22 (1/2): p. 28-31.

Goldratt, E.M. - Cox, J. (1984): The Goal: A Process of Ongoing Improvement. Great Barrington: North River Press

Hayes, R.H. - Abernathy, W.J. (2007): Managing Our Way to Economic Decline. Harvard Business Review, JulyAugust: p. 138-149.

Hinek M. (2009): Az outsourcing: A tevékenységkihelyezési döntések elmélete és gyakorlata. PTE KTK Gazdálkodástani Doktori Iskola, doktori értekezés, elérhetô: http://www.gphd.ktk.pte.hu/files/tiny_mce/ File/Vedes/Hinek_Matyas_disszertacio.pdf
Jiangyong, L. - Zhigang, T. - Linhui, Y. (2009): Mattel's strategy after its recall of products made in China. Case Study, Asia Case Research Centre, University of Hong Kong HKU810

JUSE: Union of Japanese Scientists and Engineers honlapja: http://www.juse.or.jp/e/qc/, (elérés idôpontja: 2012. november 15.)

Knowledge@Wharton honlapja: http://knowledge.wharton. upenn.edu/article.cfm?articleid=2959, (elérés idôpontja: 2012. november 15.)

Krajewski, L.J. - Malhotra, M. - Ritzman, L. (2013): Operations management: processes and supply chains. New Jersey: Pearson

Kroes, J.R. - Ghosh, S. (2010): Outsourcing congruence with competitive priorities: Impact on supply chain and firm performance. Journal of Operations Management, vol. 28, no. 2: p. 124-143.

Liker, J.K. (2004): The Toyota Way: 14 Management Principles. New York: McGraw-Hill

Mann, N.R. (1987): The keys to excellence. The story of the Deming Philosophy. 2nd ed., Los Angeles: Prestwick Books

McGrath, R. (2009): Why Vertical Integration Is Making a Comeback. HBR Blog Network, elérhetô: http://blogs. hbr.org/hbr/mcgrath/2009/12/vertical-integration-canwork.html

Outsourcing Institute honlapja: http://outsourcing.com/, (elérés idôpontja: 2012. november 5.)

Pisano, G.P. - Shih, W.C. (2012): Does America really need manufacturing? Harvard Business Review, March 2012: p. 94-101.

Saaty, T.L. (1980): The Analytic Hierarchy Process. New York: McGraw Hill

Sakai, K. (1990): The Feudal World of Japanese Manufacturing. Harvard Business Review, vol. 68, no. 6, p. 38-49.

Snow, D.C. - Wheelwright, S.C. - Wagonfeld, A.B. (2006): Scharffen Berger Chocolate Maker. Harvard Business School, 9-606-043

Spear, S. - Bowen, K.H. (1999): Decoding the DNA of the Toyota Production System. Harvard Business Review, Sept-Oct: p. 97-106.

Toyota Supplier honlapja: http://www.toyotasupplier.com/ sup_guide/sup_standards.asp (elérés időpontja: 2012. november 15 .)

Vörös J. (2010): Termelés- és szolgáltatásmenedzsment. Budapest: Akadémiai Kiadó

Watanabe, K. - Stewart, T.A. - Raman, A.P. (2007): Lessons from Toyota's long drive. Harvard Business Review, July-August: p. 74-83.

Wisner, J.D. (2008): The Chinese-made toy recalls at Mattel, Inc. esettanulmány, University of Nevada, College of Business, elérhető: http://faculty.unlv.edu/wisnerj/ mba720_files/Mattel_case2.pdf 